\title{
Sitting Ducks and Decoy Ducks: New Trends in the Indemnification of Corporate Directors and Officers
}

\author{
Joseph W. Bishop, Jr. $\uparrow$
}

A vast pother has arisen in corporate circles over the dreadful plight of officers and directors, beset on the one hand by predatory strike suitors anxious to convert them and their little families into welfare clients if their efforts to maximize the corporation's profits come to grief, beset on the other by ruthless minions of the Antitrust Division determined to throw them into the federal pen if those efforts succeed. Some, perhaps most, of the excitement has been generated by the aggressive and imaginative propaganda of underwriters pushing insurance against such hazards. ${ }^{1}$ The general tenor of the insurance companies' campaign is illustrated by its advertisements in the business press-for example, an ad which features a composite photograph of a board of directors presided over by a stuffed duck and the explanatory text, "As a corporate director or officer, you may be a sitting duck for a shareholder or third party liability suit."2 The pother is not, however, entirely synthetic; there have in recent years been a large number of highly publicized suits (or threats of suits) against directors. Most of them rested on allegations that the directors were feathering their personal nests at the corporation's expense, but a few appeared to charge nothing worse than negligence, bad judgment, or even misplaced altruism on the part of the defendant directors. ${ }^{3}$

† Professor of Law, Yale Law School. B.A. Dartmouth 1936; LL.B. Harvard 1940.

1. Such insurance has been the subject of a number of recent articles and comments in legal and other periodicals. See, e.g., Bishop, New Cure for an Old Ailment: Insurance Against Directors' and Officers Liability, 22 Bus. LAw. 92 (1966); Note, Public Policy and Directors' Liability Insurance, 67 CoLUM. L. REv. 716 (1967); Note, Liability Insturance for Corporate Executives, 80 HARv. L. REv. 648 (1967); Wallace, Facts and Fallacies of Directors' and Officers' Liability, Financlas ExEcurrve, Sept. 1967, at 2. The campaign has had considerable success. A recent survey of 753 corporations showed that nearly 20 per cent carry such insurance; the number of policies sold has risen from two in 1962 to 50 in 1966. J. BACON, Corporate Directorship Practices 124-25 (National Industrial Conference Board, 1967).

2. Wall Street Journal, March 21, 1968, at 6, cols. 4-6. See also Brook, Officers and Directors Liability Insurance, 2 ABA INSURANCE, NEGLIGENGE, AND COMPENSATION LAW SEcrion 228 (1967). And compare the full-page spread on page 9 of the same newspaper's issue of March 6, 1968, in which a sullen stockholder announces that he "might just sue every company director reading this newspaper," and reminds the presumably panicking directors that he is but one of their "24 million potential enemies."

3. E.g., Sylvia Martin Foundation, Inc. v. Swearingen, 260 F. Supp. 231 (S.D.N.Y. 1966) (dismissing stockholder's complaint for failure to join indispensable parties; dictum that stockholder did not state a derivative cause of action in charging directors with having financed European operations by borrowings in Europe at interest rate higher than those 
The real or imagined perils faced by directors have naturally stimulated their lawyers and the legislatures of most major states of incorporation to devise remedies. These take the form of by-laws and statutes authorizing indemnification of corporate executives under certain circumstances. ${ }^{4}$ With a few honorable exceptions, the object of the draftsmen of the first generation of by-laws seemed to be virtually to immunize management from personal liability. The most brazen of these older by-laws purported to permit executives adjudged guilty of breaching their duty to the corporation to be indemnified not only for their counsel fees but also for the very sums they had been ordered to pay the corporation. The recent trend among sophisticated counsel has been to eschew such naively hoggish attempts to nullify the stockholder's judicial remedy, which courts would in any case be likely to invalidate as against public policy. But though the newer by-laws flatly prohibit indemnification for amounts paid to the corporation, whether pursuant to judgment or settlement, reimbursement for other expenses is categorically banned only when the executive is actually adjudged derelict in his duties. Even the most selfdenying of them permit indemnification for counsel fees and other expenses of settling a derivative suit if "independent legal counsel" opines that the executive acted "in good faith for a purpose which he reasonably believed to be in the best interests of the corporation." Moreover, General Motors' by-law is the only one of which I am aware

charged by American lenders, apparently for the patriotic purpose of checking the rold drain); Graham v. Allis.Chalmers Mff. Co., 40 Del. Ch. 335, 182 A.2d 328 (Ct. Ch. 1962), aff'd, 41 Del. Ch. 78, 188 A.2d 125 (Sup. Ct. 1963) (holding that plaintiff stocisholder had failed to show that directors who did not detect employees' violation of the antitrust laws had not exercised due care in the circumstances). Similar to the Syltia MIortin suit is a recently reported stockholder's suit in the right of United States Steel, which charges its directors with excessive and improper corporate good citizenship in paying taxes which were not legally due because nonpayment would have had an adverese effeet on loeal tax structures. Wall Street Journal, Jan. 2, 1968, at 19, col. 3. Still more interesting is a suit threatened by the trustee in reorganization of Webb \& Knapp, an insolvent real estate corporation. According to newspaper reports, the trustee charges the directors (who in. clude the dean of a famous lav school) with negligent failure to supervise the activities of the company's dominant manager. Wall Street Journal, April 20, 1967, at 1, col. 2. N.Y. Times, April 20, 1967, at 1, col. 3.

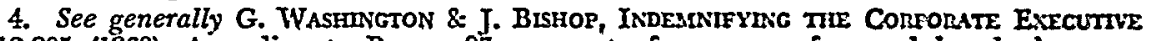
112-205 (1963), According to Bacon, 87 per cent of a group of several hundred manufacturing corporations and 77 per cent of a slightly smaller group of non-manufacturers had made provision (usually in their by-laws) for indemnification. J. BAcos, supra note 1, at 123.

5. Freeport Sulphur Company (Proxy Statement, March 14, 1965), General Motors (Proxy Statement, April 13, 1967) and Westinghouse Electric Corporation (Proxy State. ment, February 28, 1967) are examples of corporations which have recently replaced prim. itive indemnification by-laws with provisions which are both more artistically drafted and more consonant with good policy. All contain provisions essentially similar to those quoted in the text. 
that provides that stockholders must be informed of indemnification payments.

Thus these new and improved provisions offer less protection against unjustifiable indemnification of guilty insiders who elect to settle derivative suits than do the statutes-unfortunately exceptional - which permit indemnification only with court approval. "The principal uncertainty is the independence of "independent legal counsel." No one need question the honesty of these darlings of corporate draftsmen: the problem rather is that those who choose them are pretty sure to favor a lawyer who has acquired in the course of a corporate practice a sympathetic understanding of the problems of corporate management. It is not easy for even a lawyer of the most rugged integrity to be harsh to people who were responsible for his retainer. But in fact counsel may well be a regular associate and friend of the defendants: "independent" may turn out to mean nothing more than he is not an employee of the corporation. " Whether truly "independent" or not, if counsel finds the defendant executives acted "in good faith," etc., the corporation can pay their counsel fees-which may be substantially larger than the amount they pay the corporation in settlement of its claim, especially if the corporation has agreed to pay a satisfactory fee to plaintiff's counsel as part of the settlement.

The "independent counsel" feature of modern by-laws is probably modeled on a similar provision of the New York Business Corporation Law. ${ }^{8}$ But that statute, in addition to requiring judicial approval of the settlement itself, and permitting the court's approval to limit indemnification in connection with the settlement, ${ }^{\circ}$ categorically prohibits indemnification not only for amounts paid to the corporation in settlement but also for "expenses incurred in defending a threatened action, or a pending action which is settled or otherwise disposed of without court approval." 10 Such thoroughgoing insistence upon court

6. E.g., Cal. CoRp. Code \& 830(a) (West Supp. 1967); Conn. Gen. Stat. Ann. § 33.320 (Supp. 1966). The Connecticut statute permits indemnification without court approval if the director's defense has succeeded on the merits. But New York's statute, the other principal example of a legislative effort to restrict indemnification to insiders who deservo it, permits the corporation to pay a director's counsel fees incident to settlement of a derivative suit if the settlement itself had court approval, if that approval does not bar indemnification, and if "directors who are not parties to such action," "independent legal counsel," or the shareholders find that the defendant director did not breach his duty to the corporation. N.Y. Bus. CoRP. LAw $\$ \$ 722,724,726(b)(3)$ (McKinney 1963).

7. It may not even mean this much. The Westinghouse by-law, supra note 5 , provides that he may be "regular counsel of the Corporation." It is not clear whether this phrase is intended to include house counsel.

8. N.Y. Bus. CORP. LAW § 724(b)(3) (McKinney 1963).

9. Id. $\S 726(\mathrm{~b})(3)$.

10. Id. $\S 722(\mathrm{~b})$. 
supervision lessens the risk that the plaintiff stockholder and defendant director will agree upon a settlement which includes a small payment by the defendant to the corporation and a large one by the corporation to plaintiff's counsel. ${ }^{11}$

The statutory current, unlike that of the by-laws, seems to have set in the direction of greater permissiveness. The objective of the 1967 revision of the Delaware statute on indemnification ${ }^{12}$ is apparently not to place limits on the protection of guilty management, but to make explicit the power of management to indemnify itself in situations where, under the original artless enactment of an untutored legislature, courts and commentators had questioned the propriety of indemnification. The new Delaware statute deserves careful study, for it is likely to prove a prototype. Indeed, its draftsmen collaborated with those redrafting the indemnification provision of the Model Business Corporation Act, ${ }^{13}$ with the result that the two provisions are now virtually identical. Those jurisdictions which habitually follow the lead of Delaware and the Model Act ${ }^{14}$ will thus face no difficult choice of how best to demonstrate their traditional friendship for corporate management.

The old Delaware statute ${ }^{15}$ and those acts which copied it contained a number of ambiguities which the courts might have resolved against indemnification. For example, the old law did not clearly permit reimbursement for counsel fees incurred in contexts other than litigation; the 1967 statute is expressly applicable to "administrative or investigative proceedings." Similarly, by making no distinction between stockholders' suits in the corporation's right and third party suits, the old statute seemed to forbid indemnification not only when

11. Rule 23 of the Rules of the Delaware Court of Chancery, like Rule 23 of the Federal Rules of Civil Procedure, prohibits dismissal or settlement of derivative suits without the approval of the court; it has, however, no appliation to suits which are threatened but not actually filed. No doubt the desirability of making a settlement res judicata against the corporation, to bar revival of the claim by a stockholder not a party to the settlement, puts the parties under some pressure to obtain judicial approval of any compromise. But since there is no explicit requirement of court approval of any indemnifieation in connection with the settlement of a suit, even if actually filed, the Delaware Rules may permit some abuse of the by-laws allowing indemnification for attorney's fees with the approval of "independent counsel."

12. DEL. CODE ANN. tit. 8, \$ 145 (Supp. 1967). The new indemnification provision is part of a broad revision of the Delaware General Corporation Law. See generally Arsht \&: Stapleton, Delaware's New General Corporation Law: Substantive Changes, 23 Bús. LAw. $75(1967)$.

13. MODEL Bus. CORP. ACT $\S 4$ A (1967), replacing former section $4(0)$.

14. See Sebring, Recent Legislative Changes in the Law of Indemnification of Directors, Officers and Others, 23 Bus. LAw. 95, 107-09 (1967).

15. DEL. CODE ANN. tit. 8, § 122(10) (1953). It was analyzed at some length in G. WHsisINGTON \& J. BISHOP, INDEMINIFYING IHE CORPORATE EXECUTIVE 116-36 (1963). 
the executive was adjudged liable to the corporation for a breach of duty to it, but also when he was adjudged liable to an outsider for an injury committed within the scope of his duty to the corporation and with intent to further its interests; the new provision allows indem. nification of an executive in such circumstances "if he acted in good faith and in a manner he reasonably believed to be in or not opposed to the best interests of the corporation, and, with respect to any criminal action or proceeding, had no reasonable cause to believe his conduct was unlawful."10 Moreover, even if he is adjudged liable to the corporation for negligence or misconduct, the court is empowered to sanction indemnification if it thinks him equitably deserving: ${ }^{17}$ Under the old provision there was serious doubt whether even innocent in. siders could be indemnified for expenses in suits (particularly under Sections 10(b) and 16(b) of the Securities Exchange Act of 193418) based on trading in their corporation's securities. Although the insiders' asserted liability rested on their status as directors and officers, they had been trading on their own account, without intent to help or harm the corporation. According to the draftsmen of the new section, the authority to indemnify one who acted in a manner "not opposed to" the company's interests was intended to cover just such cases. ${ }^{10}$ Also, the executive had no right to be indemnified under the old statute and might be in trouble if control changed or he fell out with incumbent management. Subsection (c) of the new section provides that he "shall" be indemnified to the extent that his defense is successful, on the merits or otherwise.

The ambiguity most disturbing to management, however, lay in the failure of the original statute to deal explicitly with compromise settlements. It may be conjectured with some confidence that a stockholder's complaint is far more likely to be settled by some sort of compromise than to proceed to an adjudication of liability-if only because all the statutes and most by-laws explicitly forbid indemni-

16. § 145(a). Except for the addition of the words "or not opposed to," the clause parallels \& 723(a) of the New York Business Corporation Law.

17. \& 145(b). The clause is derived from a similar provision of the English Companies Act. See p. 1102 infra.

18. 15 U.S.C. $\$ \S 78 j(b), 78 \mathrm{p}(\mathrm{b})(1964)$.

19. S. Arsht \& W. Stapleton, Analysis of the New Delaware Corporation Law 327 (1967); Sebring, supra note 14, at 102. But in their article in The Business Lawyer the Delaware draftsmen, suggesting that the purpose of the phrase was to allow indernnifica. tion of the director who successfully defended himself against charges of having appro. priated for himself a corporate business opportunity, were rather conspicuously silent on management's power to use corporate assets to pay the counsel fees of an insider who prevails in litigation based on his trading, for his own account, in the company's stock. Arsht \& Stapleton, supra note 12, at 79. 
fication of an insider who has actually been "adjudged" guilty of negligence or misconduct. Suppose, then, that an insider, aware that the court is likely to take a dim view of his conduct if matters are allowed to proceed that far, prudently elects to compromise. While continuing to protest his innocence, he agrees to pay something to the corporation, which in turn agrees to recognize its indebtedness to plaintiff's counsel by paying him a substantial fee. Can the corporation pay the defendant's counsel fees, which may considerably exceed the damages he agreed to pay? In 1962 Delaware's Chancellor, troubled by "the unhealthy consequence of placing a director in the position where he would be assured of indemnification if he settled but would run the risk of paying his own attorney if he unsuccessfully resisted the action," questioned the applicability of the statute to defendants who settled derivative suits prior to judgment; he suggested legislative study of the problem..$^{20}$ Predictably, the result of Delaware's legislative study is explicit authority to indemnify a director "against expenses (including attorneys' fees) actually and reasonably incurred by him in connection with the defense or settlement of such action," if fellow directors who are not themselves parties, or stockholders (apparently including those who are themselves defendants), or our old friend, independent legal counsel, find that "he acted in good faith and in a manner he reasonably believed to be in or not opposed to the best interests of the corporation."21 In many derivative suits, of course, all of the directors will be named as defendants, so that management will have to choose between stockholders or independent legal counsel. It seems likely that management of a publicly-held corporation would prefer the latter alternative, which entails no problem of embarrassing disclosure. The new Delaware statute, unlike that of New York, neither requires nor permits the court to require that stockholders be notified of indemnification payments in connection with a settlement. In fact, as the reader will not be surprised to learn, the new statute contains no requirement of judicial approval of indem. nification in connection with a settlement.

On its face the word "expenses" might seem broad enough to authorize reimbursement to the defendant of even the amount paid by him to the corporation in settlement of its claim against him; the

20. Essential Enterprises Corp. v. Dorsey Corp., 40 Del. Ch. 343, 351, 357, 182 A.2d 647, 655-56 (Ct. Ch. 1962). The actual holding was that a corporation might elect, through a by-law, to limit whatever freedom the statute gave it and that the corporation in ques. tion, whose by-law excluded indemnification in case of compromise, had done so.

21. DEL. CODE ANN. tit. 8, § 145(b), (d). 
draftsmen of the earlier version of the Model Act's indemnification provision actually did so construe the term, ${ }^{22}$ although it does not appear that any court has ever done so. But the draftsmen of the new pro. visions of both the Delaware statute and the Model Act unequivocally disclaim any such intention, ${ }^{23}$ and it is highly unlikely that any court would arrive at a different construction. It is interesting to note that the Delaware draftsmen decided against permitting the corporation to return sums paid to it in satisfaction of judgment or settlement of its claim not merely because such indemnification would "subvert the substantive provisions of the corporation law," but also because "it was the committee's view that to permit such indemnification would have the ultimate effect of discouraging settlements since, in such a situation, derivative plaintiffs could demonstrate no benefit arising to the corporation from their action and, presumably, could not justify being reimbursed for their litigation expenses, including counsel fees." 24 The implication of this latter practical consideration seems to be that the statute contemplates amicable settlements of Delaware litigation, with the corporation scattering largesse among the legal dramatis personae. This would be of a piece with Delaware's general approach to stockholder litigation, which is to make it easy to sue the executives of Delaware corporations, no matter where they reside or the corporation does business, so long as the suit is in Delaware courts, and conducted by Delaware counsel.25 The new legislation breaks nobody's ricebowl.

Overall, by relying too heavily on the independence of the independent legal counsel who is to decide on indemnification in case of settlement, the Delaware statute may betray a less than ironhearted determination to protect the corporation. That aside, these sections

\footnotetext{
22. See I MODEL Bus. CORP. ACT ANN. \$ 4(0), If 4.03 (1960); Folk, Corporation Statutes: 1959.1966, 1966 DUKE L.J. 875, 912.

23. See Arsht \& Stapleton, supra note 12, at 79-80; Sebring, supra note 14, at 103. Sec. tion 145(a), dealing with third party suits, authorizes indemnification against "expenses (including attorneys' fees), judgments, fines and amounts paid in settlement actually and reasonably incurred by [the defendant director] in connection with such action. . . The draftsmanship is awkward, but it does suggest that "expenses," as the word is used in subsection (b), covering derivative suits, is not intended to include amounts paid in settle. ment.

24. Arsht \& Stapleton, supra note 12 , at 80 .

25. The Delaware legislature made no change in Sections 365 and $\$ 66$ of Titlc 10 of the Delaware Code, whose effect is to permit the sequestration of any stock owned by a defendant, no matter where he happens to reside, and thus to force out-of-state dircctors to appear in Delaware courts. Cf. Sands v. Lefcourt Realty Corp., 35 Del. Ch. 840, 117 A.2d 365 (Sup. Ct. 1955); Greene v. Johnston, 34 Del. Ch. 115, 99 A.2d 627 (Sup. Ct. 1958). Moreover, the new statute, like the old, contains no requirement that the plaintiff in a derivative suit post security for the counsel fees and other expenses of successful defen. dants.
} 
of the act arguably restrain management's power to free itself from liability for breaches of duty to the corporation as far as is possible without direct judicial power to supervise indemnification. But the last two subsections, $(f)$ and $(g)$, of Section 145 of the Delawware Law, as well as Section $4 \mathrm{~A}$ of the Model Act, throw everything back into confusion. They suggest a legislative intent to permit indemnification, directly or through insurance paid for by the corporation, in any and all circumstances.

Subsection (f) retains without important change the non-exclusive clause of the old Delaware statute: "The indemnification provided by this section shall not be deemed exclusive of any other rights to which those indemnified may be entitled under any by-law, agreement, vote of stockholders or disinterested directors or otherwise. . . ." Nobody knew what the clause meant in the old statutes, and if anyone knows what it means in the new ones, he has not published the information. Little, if any, light is shed by the statutes' sponsors. The Delaware draftsmen remark cryptically that the clause was inserted "so that other rights to indemnification may still exist by contract, by-law or charter within such limits of public policy as the courts may establish." principal draftsman of the Model Act's new provision expresses a belief that courts will be guided by "public policy considerations, possibly in the light of the substantive provisions of the statute" in deciding whether to enforce, for example, a by-law which goes beyond the statute's scope. ${ }^{27}$ If the few cases in which the issue has been presented are any guide, the courts will not be overly eager to find in the non-exclusive clause authority for the indemnification of executives who have breached their duty to the corporation..$^{28}$

26. Arsht \& Stapleton, supra note 12, at 80 . The mention of rights of indemnifieation pursuant to contract is probably intended to cover situations in which a guilty director is in a position to offer the corporation a substantial quid pro quo in exchange for its promise to indemnify him. Cf. Koster v. Warren, 176 F. Supp. 459 (N.D. Cal. 1959), aff'd, 297 F.2d 418 (9th Cir. 1961) (holding valid a promise to indemnify a director, co-defendant with the corporation in criminal antitrust proceedings, in exchange for his agrecment to switch his plea from not guilty to nolo contenderc, thereby facilitating the corporation's obtaining a favorable consent decree); Simon v. Socony-Vacuum Oil Co., 179 Misc. 202, 38 N.Y.S.2d 270 (Sup. Ct. 1942), affd mem., 267 App. Div. 890, 47 N.Y.S.2d 589 (1944) (similar facts and holding). In neither of these cases did the original litigation charge the directors with a breach of duty to the corporation. Even so, indemnifiention in such cases can be criticized as tending to frustrate the policy of the antitrust laws. See Note, Indemnification of Directors: The Problems Posed by Federal Securities and Antitrust Legislation, 76 HARv. L. REv. 1403 (1963).

27. Sebring, supra note 14 , at 105.

28. See, e.g., Teren v. Howard, 322 F.2d 949 (9th Cir. 1963); SEC v. Continental Growth Fund, CCH FED. SECURITIES L. REP. If 91,437, at 94,719 (S.D.N.Y. 1961); Esscntial Enterprises Corp. v. Dorsey Corp., 40 Del. Ch. 343, 182 A.2d 647 (Ct. Ch. 1962). In the Teren and Dorsey cases, the courts simply ignored the possibility that the directors' resolution to 
Subsection ( $f$ ) may be a manifestation of reluctance to meddle with the incomprehensible rather than a deliberate effort to geld the statute. Subsection (g) presents a greater threat. It deals with an aspect of-or, as some might have it, an answer to-the indemnification problem that could without careful legislative and judicial attention render all but nugatory any efforts to place limits on indemnification. The problem is insurance; specifically, the nature of the risks against which the corporation may purchase protection for its officers and directors. Subsection (g) at first blush (and it is certainly entitled to blush) appears to permit the executives of a corporation to relieve themselves at the company's expense of any legal obligation to manage the corporation's affairs with either honesty (provided only that they steer clear of the penal code) or diligence. It provides, with commendable candor, that

A corporation shall have power to purchase and maintain insurance on behalf of any person who is or was a director, officer, employee or agent of the corporation, ... against any liability asserted against him and incurred by him in any such capacity, or arising out of his status as such, whether or not the corporation would have the power to indemnify him against such liability under the provisions of this section. ${ }^{29}$

Delaware (and the Model Business Corporation Act) thus essay to lay at rest, by one grand, Napoleonic stroke, all the doubts about the propriety and validity of directors' and officers' liability insurance which have been expressed since the introduction of such insurance..$^{30}$ Taken literally, the subsection seems to mean that, as far as the Deliware lawgiver is concerned, a corporation may insure its management against any obligation to account to the corporation for profits from any of the numerous varieties of self-dealing, from usurping the cor. poration's business opportunities through paying themselves excessive

indemnify themselves might be valid under the Delaware statute's non-exclusive clatuse. In Continental Growth, where a charter provision authorized the indemnification of a director guilty of ordinary negligence in managing the corporation's affairs, the court pointed out that the non-exclusive clause of the Maryland statute, like that of Delawarc, saved rights "under any by-law, agreement, vote of stockholders, or otherwise" but suid nothing about charter provisions. However unconvincing the court's exegesis, it exem. plifies the attitude which judges may be expected to display when asked to sanction tho indemnification of directors whose innocence is doubtful.

29. It is not clear why the subsection speaks only of "liability," making no reference to the "expenses (including attorneys' fees)" which are specified in preceding subsections, I incline to the belief that the omission was inadvertent. But it may be that "liabllity" is intended to include the insider's obligation to pay his lawyer.

30. See note 1 supra. 
compensation to plain embezzlement, which stockholders typically allege in derivative suits. ${ }^{31}$

Despite the apparent blessing of the Delaware legislature, I would hesitate to render an unhedged opinion that even the courts of Delaware would treat as consistent with public policy, valid, and enforceable, an insurance policy paid for by the corporation whose effect was to free corporate managers from the fear of civil liability for breach of their duty to show good faith in their dealings with the corporation. Since none but the crudest breaches of the executive's duty of good faith are likely to incur criminal sanctions, the principal legal deterrent to the common varieties of self-dealing is probably fear of civil liability. ${ }^{32}$ Where the criminal law takes adequate care of deterrence, so that the main effect of insurance is to assure the compensation of the victim, the argument against allowing either the corporation or the executive himself to purchase insurance against such liability may lose some of its force; $;^{33}$ nobody has ever suggested that the familiar fidelity bond is contrary to public policy because it may weaken the effect of civil liability as a deterrent to embezzlement. But when deliberate misfeasance does not violate any criminal statute, so that deterrence is a major reason for the imposition of civil liability, the threat of such liability-as blunt an instrument as it is-appears to play an essential role. ${ }^{34}$

The problem of determining what insurance protection the corporation should be allowed to purchase for its executives is, as the preceding paragraph shows, entwined with the broader problem of what insurance coverage should be available for purchase by either the corporation or the executive. It is unlikely that insurance companies are anxious to

31. For an exhaustive catalogue and thorough discussion of the principal types of conflict of interest between directors and corporations, see Marsh, Are Directors Trustees? Confict of Interest and Corporate Morality, 22 Bus. LAw. 35, 57-73 (1966).

32. For such reasons it has been suggested that any insurance against civil liability for breach of the duty of loyalty is contrary to public policy, even if it is paid for by the director himself. See Note, Public Policy and Directors Liability Insurance, G7 Colus. L. REv. 716, 719 (1967). Cf. Note, Indemnification of Directors: The Problems Posed by Federal Securities and Antitrust Legislation, 76 HARv. L. REv. 1403, 1408.09 (1963).

33. Some courts have upheld insurance which covered civil liability for criminal acts, such as assault and battery. E.g., Wolff v. General Cas. Co. of America, 63 N.Mr. 292, 361 P.2d 330 (1961); Nationwide Mut. Ins. Co. v. Roberts, 261 N.C. 285, 134 S.E.2d 654 (1984). See Comment, Liability Insurance and Assault and Battery: Coverage and Damares Prob. lems, 50 Cornell L.Q. 506 (1965); E. Patterson, Essentuals of Insurance Lay 69, 263.66 (2d ed. 1957).

34. E.g., Northwestern Cas. Ins. Co. v. McNulty, 307 F.2d 432, 435 (5th Cir. 1962) (refusing to construe a liability insurance policy as covering punitive damages, sino ouch coverage would be against public policy and invalid); American Sur, Co. v. Gold, 375 F.2d 523 (10th Cir. 1966) (similar holding); see E. PATrERsoN, supra note 33, at 202-66. But ef. Gray v. Zurich Ins. Co., 65 Cal. 2d 263, 419 P.2d 168, 54 Cal. Rptr. 104 (1900). 
guarantee the success of managerial attempts to divert corporate assets to management's own pockets, even by methods short of larceny, any more than they would wish to insure an ordinary thief against having to return to the owner the fruits of his larcenous labors-if only because insurance which in effect encouraged the act against whose consequences it insured would be unlikely to be profitable. ${ }^{35}$ Indeed, the present standard form ${ }^{36}$ appears to intend to exclude such coverage, so far as it is possible to discern intent through the smog of its peculiar draftsmanship. Part I of the policy, which reimburses the corporation for indemnification payments made by it, covers only payments "required or permitted according to applicable law, or under provisions of the Company's charter or by-laws." Not even the Delaware statute seems to permit the corporation to indemnify against liabilities arising out of self-enrichment, and, despite the non-exclusive clause, it is unlikely that the courts would treat as valid a charter or by-law provision which purported to go beyond the statute. ${ }^{37}$

But part II of the policy, which insures the individual director or officer against liabilities and expenses for which the corporation cannot lawfully indemnify him, might well be held to cover several kinds of self-dealing. Its exclusion clause provides inter alia that

Underwriters shall not be liable to make any payment for loss in connection with any claim made against the Assureds:

(b) based upon or attributable to their gaining in fact any personal profit or advantage to which they were not legally entitled;

(c) for the return by the Assureds of any remuneration paid to the Assureds without the previous approval of the stockholders of the company which payment without such previous approval shall be held by the courts to have been illegal;

....

(e) brought about or contributed to by the dishonesty of the Assureds; however, notwithstanding the foregoing, the Assureds shall be protected under the terms of this policy as to any claims upon which suit may be brought against them, by reason of any alleged dishonesty on the part of the Assureds, unless a judg-

35. See Note, Public Policy and Directors' Liability Insurance, 67 Colum, L. REv, 716, 717 (1967).

36. The form currently most in use is the "Stewart, Smith" (or Amcrican) varicty of the Lloyd's of London Directors and Officers (Open Market) Form, which is described in Note, Liability Insurance for Corporate Executives, 80 HARv. L. REv. 648 (1967). Changes in the drafting and coverage of the policies have been frequent since their introduction about five years ago, but there is considerable room for improvement. I believe, but cannot guarantee, that the forms available to me are the most advanced.

37. See p. 1085 supra. 
ment or other final adjudication thereof adverse to the Assureds shall establish that acts of active and deliberate dishonesty committed by the Assureds with actual dishonest purpose and intent were material to the cause of action so adjudicated; . . .

When the reader's head stops spinning, he can begin to sort out the questions which throng into his mind. Is there a difference between a director's gaining a profit to which he is not legally entitled and "dishonesty"? Is excessive compensation an advantage to which an officer is not legally entitled? If it is, why is it excluded only when the reason for its illegality is the absence of stockholder approval-which is very rarely a reason for holding compensation excessive? ${ }^{38}$ If a court directed the return of remuneration for the usual reason, which is that it bore no reasonable relation to the value of the services rendered, ${ }^{30}$ the insurer would presumably be obligated to pay to the executive a sum equal to the amount by which his wages exceeded his worth-a preposterous result which it is highly unlikely that the draftsman of the policy intended. (Another version of the form, which may be later in date, excludes "salaries of officers or employees of the Company" from the definition of "loss." This would still reimburse an officer for the expenses of his unsuccessful defense; moreover, it might have no application to one to whom excessive remuneration was paid for his services as a director.)

Worse confusion follows. Is "active and deliberate" dishonesty worse than common, unadorned dishonesty, or than passive and inadvertent dishonesty? What happens if the Assured elects to settle a claim based upon dishonesty before it ripens into a judgment or other (what other?) final adjudication adverse to him?

These are merely the most glaring of the ambiguities which make the coverage of the policy so hard to figure out: the legal reader will doubtless find many more for himself. As noted, it seems improbable that these exclusions from the exclusions are intentional, and it may be supposed that at least the most absurd of them will be eliminated under the combined pressures of competition and corporate counsel who cannot, in the present condition of the policy, tell their clients what sort of pig is in the poke which they are invited to purchase. After all,

38. As a general proposition, the board of directors is legally free to set the compensation of executives without a stockholder vote, unless (in a few jurisdictions) the compensation takes the form of stock or options to purchase stock. E.g., N.Y. Bus. Corp. LAw

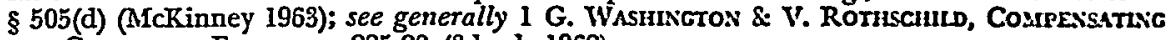
THE CORPORATE EXECUTIVE 225-28 (3d ed. 1962).

39. I G. WASHINGTON \& V. Rothschin, supra note 38, at 203 et seq. 
in three short years the draftsmanship of the Lloyd's standard form (and its American imitators) has progressed from the grotesque ${ }^{40}$ to the merely inept, and there is no reason to suppose that the underwriters' counsel have come to the end of their ability to learn. It is safe to assume that sooner or later the policy will exclude from its coverage situations in which the executive is liable (whether via settlement or adjudication) to the corporation for any form of self-enrichment at the expense of the corporation.

But while time and insurers' self-interest may tighten the definition of the risks covered in part II of the standard form, the present policy appears to cover liability for a variety of self-enriching acts by executives, for which the corporation could not lawfully indemnify them. As a concession to the reasoning that the corporation should not be permit. ted to purchase insurance against liability for which it could not directly indemnify the director, the common practice has been for the corporation to pay 90 per cent of the total premium and the director the remaining 10 per cent. ${ }^{41}$ The theory behind this happy arrangement is that the corporation's share of the premium represents the cost of coverage under part I, against liability for which the corporation could properly indemnify the director, while the director's contribution pays for the protection under part II against non-indemnifiable risks. The difficulty with the theory, as I have pointed out before, ${ }^{42}$ is that it bears small relation to reality. As the standard form is now drafted, it seems probable that far more than 10 per cent of the total coverage represents risks against which the corporation could not properly indemnify its executives, even under the new Delaware statute. ${ }^{43}$

The standard reply to this criticism has been the argument that there is a basic difference between direct indemnification and insurance;

40. The palcolithic policies are described in Bishop, supra note 1, at 103.06.

41. The argument is that if the risk insured against by part II-i.e., that part of the risk which consists of liability and expense for which the corporation could not lawfully indemnify the director-is greater than 10 per cent, then the corporation is attempting to do indirectly what it could not do directly. New York's Business Corporation Law cx. plicitly invalidates any provision for indemnification which is inconsistent with the statute. N.Y. Bus. CORP. LAW \& 721 (McKinney 1963). California's statute is similar. GAL. Conp. CODE \$ 830(e) (West 1955).

It is interesting to note that a number of New York corporations have recently replaced their pre-1963 indemnification by-laws with by-laws which provide merely that directors and officers "shall be indemnified to the fullest extent now or hereafter permitted by law. ..." E.g., General Electric Company (Proxy Statement, March 11, 1968); Long Island Lighting Company (Proxy Statement, March 7, 1968). Management may fear that New York courts, like those of Delaware, would hold that discretion to indemnify could be limited by a by-law which could be construed to be more restrictive than the statute. Sce supra note 20.

42. See Bishop, supra note 1, at 106-07.

43. See pp. 1087-90 supra. 
because the latter is "compensation," it is said, the corporation may properly pay the entire cost. ${ }^{44}$ The Delaware statute, which apparently allows the corporation to pay 100 per cent of the premium, seems to represent a retreat from the rationale that the 90.10 premium division avoids the problem of insurance by the corporation for non-indemnifiable risks, in favor of entire reliance on the compensation theory. But that theory itself seems swrong to me. Conceptually, any variety of indemnification, direct or indirect, is a form of compensation. ${ }^{4}$ But to argue from this premise that the corporation may therefore compensate its directors by purchasing insurance against all risks requires the tacit assumption that any kind of "compensation" is necessarily consistent with public policy. That assumption is patently unsound, for the courts frequently find that this or that type of executive compensation is impermissible, for a variety of reasons. ${ }^{40}$ It seems improbable that any court would uphold a contract of employment which provided that the executive should owe the corporation no duty of good faith or due care, especially if that contract were not disclosed to stockholders. But if such a straightforward attempt to avoid the responsibilities attached to corporate office would fail, it is difficult to see why the corporation should be allowed to achieve the same result by the device, differing only in technique, of purchasing insurance against liability for breaches of these duties.

The argument that the corporation should be able to purchase insurance as "compensation" therefore seems at best sophistical. So long as the law imposes on directors duties of good faith and due care, it should not permit them to evade those duties through the device of insurance purchased by the corporation. Unless the Delaware legislature really intends to relieve directors of their traditional responsibilities, the new Section 145 is simply self-contradictory. But even if the Delaware statute forbade the corporation to buy insurance against liabilities and expenses for which it could not indemnify, it would still be inadequate.

First, as a practical matter, it is all but impossible to prevent the corporation from buying insurance against liability for breaches of the duty owed it by directors through the simple expedient of increasing

44. This is the reasoning adduced by the draftsmen as a justification for subsection (g) of the Delaware statute. See Arsht \& Stapleton, supra note 12, at 80. See also Note, Liability Insurance for Corporate Executives, 80 HARv. L. REv. 648, 669 (1967).

45. See Sorensen v. Overland Corp., 242 F.2d 70, 73 (3d Cir. 1957).

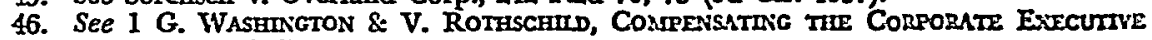
232 et seq. (3d ed. 1962). 
their general compensation by the comparatively small amount necessary to permit them to pay from their own pockets for the liability in. surance which it simultaneously negotiates on their behalf. Second, public policy should not permit even the executive himself to purchase insurance against liability for those breaches of duty for which the corporation could not indemnify him, with the possible exception of liability for "ordinary" negligence. The need seems to be for regulation of the coverage of the insurance available on the market, whether paid for by the corporation or by the director himself.

Thus, where civil liability is the sole or principal legal deterrent to self-enrichment at the corporation's expense, the director should not be permitted to insure himself against such liability, even if he can find an insurer willing to write such a policy. For like reasons, directors should not be allowed to insure themselves against liability based on negligence of a gross description, amounting to total abdication of the responsibility imposed upon them by law.

The evil of the decoy duck director, whose main function is to give to actual and potential public investors a false feeling of security, has long been recognized as real and serious. ${ }^{47}$ There seems to be a general consensus that outside directors-i.e., directors who are not full-time employees of the corporation-are desirable: even the New York Stock Exchange urges "companies not having outside directors ... to consider the desirability of doing so." 48 A recent survey of 456 manufacturing companies showed only six with no outside directors; nearly two-thirds had an outside majority. ${ }^{40}$ In 1966 even Standard of New Jersey, the leading holdout among publicly held corporations, capitulated and nominated two outside directors, who were soon followed by two more. 50

Outside directors are thought to be desirable for a number of reasons, including their special knowledge and experience and their connections with other businesses, ${ }^{61}$ but the principal justification for their presence, in theory and perhaps in practice, is the expectation that they will supervise, not to say police, the active management of the corporation -playing in this respect a role analogous to that of the Aufsichtsrat, or

47. See, e.g., Dwight, Liability of Corporate Directors, 17 XaLE L.J. 33 (1907); Douglas, Directors Who Do Not Direct, 47 HARv. L. REv. 1305 (1934).

48. N.Y. Stock Exchange, Company Manual, at B-23. See Fortune, July 15, 1966, at 71.

49. J. Bacon, Corporate Directorship Practices 6 (National Industrial Conference Board, 1967).

50. Standard Oil Company of New Jersey, 1966 Annual Report, March 9, 1967, at 6.7.

51. J. Bacon, supra note 49 , at 7,14 . Bankers and lawyers are particularly favored. 
Supervisory Council, of a German corporation. ${ }^{62}$ Outside directors who do not supervise may be dangerous in much the same way that a quack cancer cure is dangerous; reliance upon them inhibits resort to other and more effective remedies. The temptation to treat a directorship as "an avocation, a luxury, a compliment paid to a successful business or professional man, something like the bestowal of an honorary degree,"53 seems to be as great today as ever. The American (and probably world) champion director of 1966, a 76-year-old Boston banker, sat on the boards of 43 corporations, some of them very large. He may, of course, resemble Caesar and Napoleon in his ability to direct several diverse operations simultaneously, but it is also possible that he does not closely supervise all of the 43 managements. So far as I know, it is not a crime to be a director who does not direct; at least I am not aware that any director has ever been sent to jail for aggravated abdication of his responsibilities. The only legal deterrent to such conduct, and perhaps the only substantial deterrent of any sort, is the fear of civil liability. It seems to me that the desirability of compensating the victims of such gross directorial negligence is outweighed by the desirability of deterring it (especially in view of the fact that the holders of multiple directorships are often magnates rich enough to pay the damages from their own fortunes), and that insurance against it ought to be held contrary to public policy. Indeed, underwriters would exclude it from coverage if they intelligently consulted their own interest, for such negligence, amounting to an abdication of responsibility, is practically intentional: the existence of insurance against such liability is likely to encourage the conduct on which the liability is grounded.

There may, however, be one area where the limits which public policy should place upon insurable risks may diverge from the limits which should be imposed on the corporation's freedom to purchase insurance for directors. When liability rests on no more than an ordinarily negligent breach of duty to the corporation, the desirability of compensating the victim would appear to outweigh the risk that the existence of insurance will increase the frequency of the wrongful conduct. In negligent malpractice cases, the fact that civil liability is usually the only legal deterrent is not regarded as a reason for preventing

52. The Aufsichtsrat, whose members are elected by the stockholders and, under the "codetermination" provisions of the statute, by the emplojees, selects the Vorstond, or active management. No member of the Aufsichtsrat may be a member of the Dorstand. Vagts, Reforming the "Modern" Corporation: Perspectives from the German, 80 Funv. L. REv. $23,50-53$ (1966).

53. Dwight, supra note 47 , at 33.

54. See TIME, Sept. 9, 1966, at 94. 
physicians from insuring their patients against uncompensated injury by insuring themselves against such liability. There does not seem to be any compelling reason to distinguish the cases involving ordinary negligence on the part of corporate directors. Since the misfeasance is not deliberate, the deterrent value of civil liability is not great enough to require protection by such a prohibition of insurance. On the other hand, the liability is and should be non-indemnifiable, and therefore the corporation should not be allowed partially to relieve the director of his duty of care by purchasing insurance.

Ideally, therefore, coverage for this risk should be severed from the policy for which the corporation is allowed to pay, and made available only if purchased by the director. Because of the difficulty, mentioned earlier, of preventing the corporation from paying for such coverage indirectly by increasing the general compensation of the director, it seems worthwhile to examine the frequency with which liability is imposed for such simple negligence. Perhaps the problem can be solved by the application of the maxim, de minimis non curat lex. If cases of this sort are sufficiently rare, as they seem to be, such Levitical scrupulosity, merely to vindicate a principle of minimal practical importance, may be more trouble than it is worth. Such a solution might, moreover, have the great practical advantage of allaying the worries of honest corporate managers, for it is precisely this type of liability to which the main thrust of the insurance brokers' advertising is directed and which is brought forward as the principal reason for legislation authorizing the corporation to buy such insurance for its executives. ${ }^{\mathrm{bb}}$

All of the commentators, of course, recite the proposition that a corporation's directors have a duty to conduct its affairs with diligence and prudence. ${ }^{58}$ Many state corporation statutes contain provisions codifying the obligation; ${ }^{57}$ their phraseology, like that employed by the courts, is diverse and may be intended to create a variety of standards of care. ${ }^{58}$ Whether intended to do so or not, the effect of some statutes

55. See S. Arsht \& W. Stapleton, ANalysis of the New Delaware Corporation law $328(1967)$.

56. E.g., M. Feuer, Personal Llabilities of Corporate Directons and Officers 14-23 (1961); W. Fletcher, CoRporations \$\$ 989-1100 (perm. ed.); H. HENn, CoRporations § 295 (1961); 1 G. Hornstern, Corporation Law and Practice \& 446 (1959); Dyson, The Director's Liability for Negligence, 40 IND. L. REv. 341 (1965); Nielsen, Directors Duties under Anglo. American Corporation Law, 43 U. DET. L.J. 605, 609 (1966).

57. E.g., N.Y. Bus. CoRp. LAw \& 717 (McKinney 1963); PA. STAT. ANN. tit. 15, \& 1408 (1953). See also Adkins \& Janis, Some Observations on Liabilities of Corporate Directors, 20 Bus LAw. 817 (1965), which discusses inter alia the varying statutory standards of care in particular situations, such as the declaration of dividends.

58. See Dyson, supra note 56, which catalogues in some detail the verbal formulac em. ployed by courts and legislatures. Professor Dyson concludes that all leave too much lecway

\section{4}


may in fact be to increase or lessen the quantum of diligence expected of a director. For example, the draftsmen's notes to Section 717 of the New York Business Corporation Law, which prescribes "that degree of diligence, care and skill which ordinarily prudent men would exercise in similar circumstances in like positions," suggest a purpose to distinguish between inside and outside directors. ${ }^{50}$ On the other hand, the Supreme Court of Pennsylvania recently declared that Section 1408 of that Commonwealth's Business Corporation Law, which requires of directors of business corporations "that diligence, care and skill which ordinarily prudent men would exercise in similar circumstances in their personal business affairs," 60 has transformed Pennsylvania's easygoing common law standard into one which "is harsh and strict and ... may well render unattractive positions as directors of business corporations."61

But whatever terror these legislative and judicial menaces may strike into the hearts of directors is probably unjustified. The hard fact is that cases in which directors of business corporations are held liable, at the suit of stockholders, for mere negligence are few and far between. As an uncommonly frank judge put it, "it is only in a most unusual and extraordinary case that directors are held liable for negligence in the absence of fraud, or improper motive, or personal interest." 02 The observation was made 20-odd years ago but is still valid. The ado about the liability of directors for mere negligence is like the proverbial shaving of pigs-much squeal and little wool, at least for the stockholders.

Most of the cases usually cited as examples of director's liability for negligence fall into a special category not at all typical of modern American corporate life. Such cases involved banks or, occasionally, other monied corporations such as investment companies; the bank was generally insolvent, so that whatever was recovered would probably benefit depositors (a class of creditors for whom in the days before the Federal Deposit Insurance Corporation the courts displayed particular

for construction and application to be of much practical use as guides to managerial conduct.

59. N.Y. Joint legislative Conim. to Study Revision of Corp. Lays, Reuised SuppleMENT TO FIFTH INTERM REPORT to 1961 SESSION OF NEY YORE STATE LEGISLATURE, LEE. Doc. No. 12, at 5 (1961).

60. Pa. Stat. AnN. tit. 15, \& 1408 (1953) (emphasis added).

61. Selheimer v. Manganese Corp. of America, $423 \mathrm{~Pa} .563,578,224$ A.2d 634, 643 (1960). But the court's strictures were only dicta, for it concluded that the defendant directors would have been liable even under the common law test.

62. Bayer v. Beran, 49 N.Y.S.2d 2, 6 (Sup. Ct. 1944). 
solicitude) rather than stockholders; ${ }^{63}$ the negligence of the directors, which generally took the form of supinely allowing dishonest managers to play ducks and drakes with the depositors' money, could be characterized by such pejoratives as "gross" or an "utter abdication of . . . common-law responsibility"; 64 and the directors themselves usually furnished the occasion for rhetoric yet more colorful-they were "mere figureheads," 65 or "gilded ornaments of the institution, to . . . be used as a lure to customers," 66 or guilty of regarding a directorship as "a mere position of honor void of responsibility." 67

As early as 1742 the Stammvater of this line of cases, The Charitable Corporation $v$. Sutton, ${ }^{68}$ already exhibited most of the breed's distinctive traits. The Charitable Corporation was a sort of eleemosynary hockshop, whose object was "to assist poor persons with sums of money by way of loan, to prevent them falling into the hands of pawnbrokers." Its 50-odd committeemen (i.e., directors) were men of substance and good repute, but only five of them actively interested themselves in its affairs. The activities of the five took the form of causing the corporation's funds to be lent to themselves and their accomplices upon inadequate or fictitious collateral. "The loss," said Lord Chancellor Hardwicke, obviously greatly impressed, "is prodigious, for . . . the money

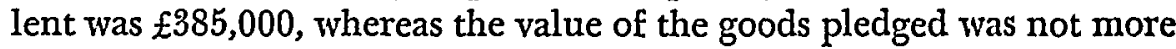

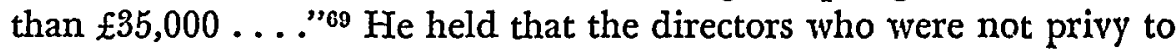
the swindle were guilty of "crassa negligentia," in essence because of their total failure to check up on the active management, ${ }^{70}$ and held

63. Some courts for this reason said that bank directors were to be held to an $\mathrm{ex}$ ceptionally high standard of diligence. See, e.g., Atherton v. Anderson, 99 F.2d 883, 888 (6th Cir. 1938); Pirott v. Heinen, 137 Kan. 186, 192, 19 P.2d 723, 727 (1933); Greenficld Sav. Bank v. Abercrombie, 211 Mass. 252, 255, 97 N.E. 897, 899-900 (1912); Broderick v. Matrcus, 152 Misc. 413, 418, 272 N.Y.S. 455,461 (Sup. Ct. 1934). In fact, whenever creditors were the beneficiaries of a recovery from delinquent directors, the courts may have been influenced by the old theory, now either moribund or entirely defunct, that the assets of a corporation were a "trust fund" for creditors. Scovill v. Thayer, 105 U.S. 143, 154 (1882); Wood v. Dummer, 30 F. Cas. 435 (No. 17,944) (C.C.D. Me. 1824); See W. Cook, PRINcipless or: CoRporation LAW 76 (1925). Even where the insolvent corporation was of the ordinary industrial or mercantile kind, courts sometimes talked the language of breach of trust. See, e.g., Nix v. Miller, 26 Colo. 203, 206, 57 P. 1084, 1085 (1899); Folsom v. Smith, 113 MIc 83, 89, 92 A. 1003, 1006 (1915); New York Credit Men's Adjustment Bureau v. Weiss, 805

N.Y. $1,7,110$ N.E.2d 397,398 (1953).

64. Bowerman v. Hamner, 250 U.S. 504, 511, 514 (1919).

65. Chicago Title \& Trust Co. v. Munday, 297 I11. 555, 562, 131 N.E. 103, 105 (1921).

66. Gibbons v. Anderson, 80 F. 345, 350 (C.C.W.D. Mich. 1897).

67. Kavanaugh v. Gould, 223 N.Y. 103, 106, 119 N.E. 237, 238 (1918).

68. 26 Eng. Rep. 642 (Ch. 1742). A century and a half later Mr. Justice Fiarlan, dissent. ing from an opinion refusing to hold liable the dummy directors of an insolvent national bank, described the old case as "very instructive." Briggs v. Spaulding, 141 U.S. 132, 171.72 (1891).

69. 26 Eng. Rep. at 643.

70. Id. at 644 . 
them liable to make good the corporation's losses: "If some persons are guilty of gross non-attendance, and leave the management intirely to others, they may be guilty by this means of the breaches of trust that are committed by others."71

American courts applied the Chancellor's reasoning to do-nothing directors of the insolvent banks whose carcasses littered the financial landscape from the early days of the republic until well into the present century. ${ }^{72}$ Even so, many a useless director escaped, for some judges displayed what a sarcastic commentator described as "good-humored tolerance"73 of rustic worthies who supposed that a seat on the board of the village bank was not so much a job as a tribute to their standing in the community. Probably the most notorious example of such judicial indulgence is Briggs $v$. Spaulding, ${ }^{7 *}$ in which five justices of the Supreme Court, considering the age, decrepitude, and inexperience of a bank's directors, managed to find their confidence in and failure to police the thieving president (who was, as the Chief Justice emphasized, not only a regular churchgoer but the treasurer of the local Young Men's Christian Association" ${ }^{75}$ up to the standard of "ordinarily prudent and diligent men ... under similar circumstances." "ic Four Justices, led by Harlan, dissented vigorously, ${ }^{77}$ and the decision has been much criticized; $^{78}$ but neither its complaisant attitude nor its result was by any means unique. ${ }^{79}$

Some of the bank cases, of course, deviate from the pattern in more or less minor ways. Thus, a few were brought by stockholders rather than receivers, trustees in bankruptcy or state officials acting for the

71. Id.

72. Among the cases most frequently cited are Bates v. Dresser, 251 U.S. 524 (1920); Bowerman v. Hamner, 250 U.S. 504 (1919); Briggs v. Spaulding, 141 U.S. 132 (1891); Gamble v. Brown, 29 F.2d 366 (4th Cir.), cert. denied, 279 U.S. 839 (1928); Warner v. Penoyer, 91 F. 587 (2d Cir. 1898); Gibbons v. Anderson, 80 F. 345 (C.C.W.D. Mich. 1897); Chicago Title \& Trust Co. v. Munday, 297 Ill. 555, 131 N.E. 103 (1921); Percy v. Millaudon, 8 Mart. (N.S.) 68 (La. 1829) (suit by stockholders rather than a receiver). Campbell v. Watson, 62 N.J. Eq. 396, 50 A. 120 (Ch. 1901), contains an cxhaustive survcy of the nineteenth-century bank cases. Many of these cases were cited for vigorous dicta affirming the directors' duty of care rather than for any imposition of actual liability. Sec note 79 infra.

73. Dwight, Liability of Corporate Directors, 17 YALE L.J. 33, 38 (1907).

74. 141 U.S. 132 (1891).

75. Id. at 158-59.

76. Id. at 152 .

77. Id. at 166.

78. See, e.g., Dwight, supra note 73, at 37-38. Learned Hand called it "a case . . which to-day would probably have gone the other way. ..." Barnes v. Andrews, 298 F. 614, 616 (S.D.N.Y. 1924).

79. See, e.g., Bates v. Dresser, 251 U.S. 524 (1920); Warner v. Penoyer, 91 F. 587 (2d Cir. 1898); Wheeler v. Aiken County Loan \& Sav. Bank, 75 F. 781 (C.C.D.S.C. 1890); Wallach v. Billings, 277 III. 218, 115 N.E. 382 (1917), cert. denied, 244 U.S. 659 (1917); Goodwin v. Simpson, 292 Mass. 148, 197 N.E. 628 (1935). The last two cases cannot be explained in terms of judicial sympathy for hayseed directors entangled in the webs of high finance. 
benefit of depositors. ${ }^{80}$ In a very few cases, the negligence on which liability was predicated took a form other than abdication of the board's duty to supervise active management, although the adjectives employed by the courts suggest that they viewed the directors' mismanagement as something worse than ordinary negligence. In. Hun v. Gary, ${ }^{81}$ the court branded the decision of the directors of a shaky bank to erect an "imposing ediffice" in an effort to lure depositors as "improvidence" and "reckless, unreasonable extravagance." In Litwin v. Allen, ${ }^{82}$ directors of the Guaranty Trust Company, which was not exactly a country bank, in the fall of 1930 authorized a deal whereby the bank bought convertible debentures of the Missouri Pacific Railroad from Allegheny Corporation (then the principal holding company of the brothers Van Sweringen), at the same time giving Allegheny an option to repurchase them at the same price within six months. The price of the debentures fell, and Allegheny, of course, declined to repurchase. The heads-I-wintails-you-lose aspect of the deal led the court to describe it as "so im. provident, so risky, so unusual and unnecessary as to be contrary to fundamental conceptions of prudent banking practice." 83 Although the court said that "the honesty of the directors in this case is unques. tioned," 84 it has been suggested that the real explanation of the decision is that the judge, suspecting but having no proof of dishonesty, bottomed liability on negligence. ${ }^{85}$ A more likely explanation, I think, is that the bank, already too deeply involved in the fortunes of Allegheny, was so reluctant to see it go under that the directors were willing to pour in more money on almost any terms which Allegheny's management would accept. If so, the case must still be regarded as one of the rare examples of liability for bad judgment, albeit extraordinary bad judgment.

It would be unprofitable to dissect further this class of cases, the principal authorities for the proposition that directors may be held liable for honest negligence. The class has been virtually extinct for a

80. E.g., Wallach v. Billings, 277 Ill. 218, 115 N.E. 382 (1917); Kavanaugh v. Gould, 223 N.Y. 103, 119 N.E. 237 (1918); Litwin v. Allen, 25 N.Y.S.2d 667 (Sup. Ct. 1940); Gallin v. National City Bank, 155 Misc. 880, 281 N.Y.S. 795 (Sup. Ct. 1935); Warren v. Robison, 19 Utah 289, 57 P. 287 (1899); O'Connor v. First Nat'1 Investors' Corp., 163 Va. 908, 177 S.E. 852 (1935). In the Wallach and Warren cases the bank was in fact insolvent, and in O'Connor the plaintiffs, "mostly inexperienced women," were stockholders in an invest. ment company who could be and were analogized to bank depositors.

81. 82 N.Y. 65 (1880).

82. 25 N.Y.S.2d 667 (Sup. Ct. 1940).

83. Id. at 699 .

84. Id.

85. See Note, Public Policy and Directors Liability Insurance, 67 CoLum. L. REv. 716, 723 (1967). 
quarter of a century, partly because of the Federal Deposit Insurance Corporation and other New Deal reforms, and partly, no doubt, because the trend toward fewer and larger banks has made inexperienced and gullible bank directors scarcer than they used to be. The modern cases which fit into the general category are comparatively few and involve monied corporations other than banks-frequently, investment companies. ${ }^{86}$

The search for cases in which directors of industrial corporations have been held liable in derivative suits for negligence uncomplicated by self-dealing is a search for a very small number of needles in a very large haystack. Few are the cases in which the stockholders do not allege conflict of interest, still fewer those among them which achieve even such partial success as denial of the defendants' motion to dismiss the complaint..$^{87}$ Still, it cannot be denied that there is a small number of relatively recent cases which do seem to lend a modicum of substance to the fears of directors of industrial or mercantile corporations that they may be stuck for what they like to call "mere" or "honest" negligence. My own collection, based on extensive (although not exhaustive) investigation, includes four such specimens. The oldest is Clayton v. Farish, ${ }^{83}$ holding that stockholders stated a derivative cause of action when they charged the directors of Standard Oil of New Jersey with negligent failure to look out for Standard's interests when, pursuant to a cartel agreement with I. G. Farben, they agreed that Standard would give up the chemical business which should have developed from its primary activities in oil. New York Credit Men's Adjustment Bureau v. Weiss ${ }^{\text {so }}$

86. E.g., Heit v. Bixby, 276 F. Supp. 217 (E.D. Mo. 1967); Neese v. Brown,-Tenn,405 S.W.2d 577 (1964); Lutz v. Boas, 39 Del. Ch. 585, 171 A.2d 381 (Ct. Ch. 1961). The outside directors whom the court in the Heit case found to have "totally abdicated their duties" did not actually have to pay anything, for the court held them entitled to indemnification by the self-dealing inside directors, who paid nearly a million dollars to settle the case. See Wall Street Journal, Oct. 20, 1967, at 22, col. 4. See generally Eisenbers \& Phillips, Mutual Fund Litigation-New Frontiers for the Investment Company Act, 62 Coluns. L. REv. 73 (1962); Mrundheim, Some Thoughts on the Duties and Responsibilities of Unaffiliated Directors of Mutual Funds, 115 U. PA. L. REv. 1058 (1967).

87. Professor Dyson has examined at some length the variety of reasons which the courts have adduced for refusal to hold directors liable for mere negligence. Prominent among them are the plaintiff's lack of standing to sue, his failure to show causation (i.e., that the loss would not have occurred had the director done his duty), and, of course, the business judgment rule. Dyson, supra note 56 . Recent unsuccessful efforts to hold directors liable for mismanagement not arising from self-dealing include, in addition to the Sylvia Martin and Graham cases mentioned note 3 supra, Warshaw v. Calhoun, - Del. Ch. $\longrightarrow, 221$ A.2d 487 (Sup. Ct. 1966) and Gilbert v. Burnside, 13 App. Div. 2d 982, 216 N.Y.S.2d 430 (196I), aff'd mem., 11 N.Y.2d 960, 183 N.E.2d 325, 229 N.Y.S.2d II (1962) (reversing Supreme Court's holding (197 N.Y.S.2d 623) that the defendant directors were liable for causing the corporation to incur heavy expenses incident to an abortive acquisition which they should have known was invalid).

88. 191 Misc. 136, 73 N.Y.S.2d 727 (Sup. Ct. 1947).

89. 305 N.Y. 1, 110 N.E.2d 397 (1953). 
held that directors who sold the assets of a liquidating corporation at public auction without adequate notice to either creditors or the public would be liable to its trustee in bankruptcy under a statute obligating directors to pay to the corporation or its creditors the value of property "lost, or wasted, by or through any neglect of or failure to perform or other violation of their duties," 80 unless they could show that they had in fact realized as high a price as was possible in the circumstances. Syracuse Television, Inc. v. Channel 9, Syracuse ${ }^{21}$ held that a stockholder stated a cause of action in charging directors, under the same statute, with wasting assets by paying excessive salaries to employees (not including themselves) and allowing the employees to engage in sundry forms of petty graft at the corporation's expense. Finally, Selheimer v. Manganese Corporation of America ${ }^{22}$ seems actually to have held directors liable in a derivative suit for "gross mismanagement" which led to the company's insolvency.

But to my mind none of these cases carries real conviction. Clayton and Channel 9 held no more than that the allegations stated a cause of action: the plaintiffs had still to hurdle all the obstacles to actual recovery in such a suit. ${ }^{93}$ In Channel 9, indeed, the court could hardly have dismissed the complaint, since it was cast in the terms of the statute. In Weiss, we do not know whether the directors ever had to pay anything; on remand they may have convinced the trial court that the company's assets would have fetched no more money in a better-advertised sale. Moreover, Weiss must be regarded as a sport; there was a cogent dissent, ${ }^{94}$ and it does not seem to have been followed in any subsequent decision of the New York courts. ${ }^{05}$ On its face, Selheimer undoubtedly holds directors liable for failing to discharge their duties "with that diligence, care and skill which ordinarily prudent men would exercise under similar circumstances in their personal business affairs." But the facts are heavy with the odor of self-dealing. The judge of the Court of Common Pleas who originally heard the case, sitting as chancellor, found "wilful misconduct and a pattern of self-enrichment by the managing defendants." Though a majority of the court en banc

90. N.Y. GEN. CORP. LAw $\$ 60(2)$ McKinney 1943). The provision was substantially reenacted in $\$ 720(\mathrm{a})(\mathrm{I})$ (B) of the N.Y. Bus. CoRP. LAw (McKinney 1963).

91. 51 Misc. 2d 188, 273 N.Y.S.2d 16 (Sup. Ct. 1966).

92. $423 \mathrm{~Pa} .563,224$ A.2d 634 (1966). See p. 1095 supra.

93. See note 87 supra.

94. By Desmond and Fuld, JJ., 305 N.Y. at 11,110 N.E.2d at 400

95. One case distinguished it on the ground that it was limited to situations in which the directors intended to wind up the business. Doyle v. Gordon, 158 N.Y.S.2d 248, 261 (Sup. Ct. 1954). 
disagreed and found no "fraud, self-dealing or personal profit gained," the Pennsylvania Supreme Court declared obiter that the record fully supported the chancellor's findings. ${ }^{96}$ The decision seems to be one of those in which "negligence" is a euphemism for dishonesty. 97 All in all, I remain very skeptical of the proposition that directors of industrial corporations run any substantial risk of liability for ordinary negligence. There is, in fact, little precedent for liability even for the kind of Merovingian supineness for which directors were held liable in the old bank cases. ${ }^{98}$

Therefore, if part II of the standard insurance policy were redrafted to cover only liability for ordinary negligence, I would feel that 10 per cent, or perhaps even one per cent, of the total premium would represent a more than fair assessment of the incidence of the risk, at least in the case of the ordinary industrial or mercantile corporation. In my opinion the cases in which a director is adjudged liable, or compelled to settle, a derivative suit based on nothing worse than ordinary negligence do not amount to one in a hundred. Such a redrafting of the standard form would properly allow the corporation to pay so large a share of the premium that there seems no practical reason to prevent it from paying the entire cost.

Such an arrangement would allow insurance, whether paid for by the corporation or the director, only against indemnifiable risks and ordinary negligence. It may be suggested that there are such things as breaches of the director's duty of good faith and loyalty which are morally innocent, and that it ought to be possible to protect directors against liability to the corporation for such breaches. It is true that in recent decades the courts have tended to expand the duty of loyalty by condemning varieties of self-dealing which previously had been re-

96. $423 \mathrm{~Pa}$ at $584-85,224 \mathrm{~A} .2 \mathrm{~d}$ at 646 .

97. Cf. Gerdes v. Reynolds, 28 N.Y.S.2d 622 (Sup. Ct. 1941). It should be noted that in Clayton $v$. Farish the complaint alleged not only negligence but also that the defendant directors had received substantial personal benefits as the price of selling out Standard. 191 Misc. at 161, 73 N.Y.S.2d at 751.

98. Perhaps mention should also be made of another type of directors' liability which cannot neatly be classified as a breach of either the duty of good faith or that of due care. These are the cases in which the plaintiff stockholder charges directors with crcessive and imprudent zeal in their efforts to maximize the corporate profits, typically by violating the antitrust laws. E.g., Knopfler v. Bohlen, 15 App. Div. 2d 922, 225 N.Y.S.2d 609 (1962); Borden v. Cohen, 231 N.Y.S.2d 902 (Sup. Ct. 1962). Such suits have been uncommon, in part because the plaintiff may be faced with the difficult task of proving that crime did not pay-i.e., that the amounts of the corporation's fines and other expenses were greater than its illicit profits. See Forte, Liabilities of Corporate Officers for Violalions of Fiduciany Duties Concerning the Antitrust Laws, 40 IND. I.J. 313 (1965); Recent Developments, Pleading and Proof of Damages in Stockholders Derivative Actions Based on Antilrust Con. victions, 64 ColuM. L. REv. 174 (1964). 
garded as legal and even ethical-for example the use of corporate funds to beat off the wicked raider and preserve the jobs of the virtuous management-and it is arguably unfair to penalize the executive who furnishes the occasion for a jurisdiction's first decision that particular conduct has ceased to be permissible. ${ }^{98}$ It is not an answer to say, as does one commentator, ${ }^{100}$ that directors should be deterred from conduct whose propriety is even dubious; if directors had to eschew every conflict of interest which a judge might hold improper, the argument that no man with substantial outside business interests would care to become a director of a publicly held company would carry more weight than it does at present. But insurance does not seem to be the answer to the question. It would be hard to draft a clause precisely defining the sort of self-dealing which is morally innocent in such a way as to avoid leaving too much to the discretion of "disinterested" directors or "independent" legal counsel. It would be just as hard to draw a line between the illicit profits which even a morally innocent director should be compelled to disgorge and the damage to the corporation (which may be greater than the benefit to the director from the selfdealing) ${ }^{101}$ which he should not be compelled to pay. It is safer to leave to the courts the relief of the morally innocent director. One device is embodied in the British Companies Act of 1948, which provides that

If . . . it appears to the court hearing the case that the officer . . . is or may be liable in respect of the negligence, default, breach of duty or breach of trust, but that he has acted honestly and reasonably, and that, having regard to all the circumstances of the case, ... he ought fairly to be excused for the negligence, default, breach of duty or breach of trust, that court may relieve him, either wholly or partly, from his liability on such terms as the court may think fit. ${ }^{102}$

The new Delaware statute and the Model Act do in fact confer a similar authority upon the court. ${ }^{103}$ Even without such statutory authority, a court might in such circumstances lay down the new law prospectively, as is often done in other tort contexts. ${ }^{104}$

99. See Folk, Corporation Statutes: 1959-1966, 1966 DUkE L.J. 875, 909.911.

100. See Note, Public Policy and Directors' Liability Insurance, 67 ColvM. L. Ruv. 716, 720 (1967).

101. Id. at 721 .

102. I1 \& 12 Geo. 6 , c. $38, \S 448(1)$. Subsection (2) provides for declaratory judicial rc. lief where an officer "has reason to apprehend" that a claim may be made against him for negligence, default, etc. Under the indemnity by-law permitted by Regulation 186 of Table A of Schedule 1 to the Act, an officer thus relieved of liability under section 148 is to be indemnified (presumably for his expenses of litigation) by the corporation.

103. DeI. CODE ANN. tit. 8, \& 145(b) (Supp. 1967); MOdEL Bus. Corf. AGr \& 4A (1967).

104. E.g., Great Northern Ry. v. Sunburst Oil \& Refining Co., 287 U.S. 858 (1052); 
In sum, I think that the practice of protecting corporate executives against litigation and liability has now been carried about as far as it ought to be carried and perhaps a little farther. Corporate directors and officers should eschew efforts to protect themselves, by direct indemnification or insurance, from the consequences of breach of their duty not to enrich themselves at the corporation's expense and from the consequences of their gross negligence in the management of its affairs. And if directors and officers do not show such self-restraint, then legislatures and courts should supply the deficiency.

Spanel v. Mounds View School Dist. No. 621, 264 Minn. 279, 118 N.TV.2d 795 (1962). See Keeton, Creative Continuity in the Law of Torts, 75 HARv. L. REv. 463,486 (1951); Note, Prospective Operation of Decisions Holding Statutes Unconstitutional or Overruling a Precedent, 60 HARv. L. REv. 437 (1947). 